\title{
Perceiving Competitiveness under the Restructuring Process of Globalization
}

\author{
Charis Michael Vlados ${ }^{1}$, Nikolaos Deniozos ${ }^{2,3}$, Demosthenes Chatzinikolaou ${ }^{4} \&$ Michail Demertzis $^{5}$ \\ ${ }^{1}$ Department of Economics, Democritus University of Thrace, Greece \\ ${ }^{2}$ Department of Turkish Studies and Modern Asian Studies, National and Kapodistrian University of Greece, \\ Greece \\ ${ }^{3}$ Department of Economics, Democritus University of Thrace, Greece \\ ${ }^{4}$ School of Law, Postgraduate Courses in Southeastern Europe Studies, Specialization in Economics, \\ Democritus University of Thrace, Greece \\ ${ }^{5}$ Department of Political Science and History, Panteion University, Greece
}

Received: April 23, 2018

doi:10.5539/ijbm.v13n8p135
Accepted: June 4, 2018

Online Published: June 30, 2018

URL: https://doi.org/10.5539/ijbm.v13n8p135

\begin{abstract}
Currently, it is becoming progressively clearer within the international scientific community that there is no narrow economic reasoning which could lead to an evolutionary conception of globalization. Under such circumstances, the contemporary globalization crisis emerges as a new center of research for all the converging socio-economic sciences.

The current article proposes a new analytical architecture to approach the current dynamics of globalization, by trying to comprehend the underlying evolutionary socio-economic process and by placing the living capitalist firm as a central concept in this analytical framework. In particular, it conceptualizes the capitalistic enterprise as an open living system-under a constant synthesis of Stra.Tech.Man terms (the interconnection between Strategy, Technology and Management). It studies business as an agent of action which both creates and is created by the socio-economic environment within a continuously systemic process, while perceiving all the sectoral and cross-sectoral dynamics as dialectic agents of the globalizing evolution.
\end{abstract}

Finally, we propose perceiving competitiveness as synthesis of business dynamics, socio-economic spaces and sectoral structures in global level, and draw the conclusion that it is analytically useful and fruitful to understand competitiveness as an organic-strategic process.

Keywords: competitiveness, globalization, innovation, interspatial development, Stra.Tech.Man analysis

\section{Introduction and Conceptual Framework: The Current Restructuring of Globalization}

In our times it is obvious that, in order to truly perceive globalization as an evolutionary unity, a one dimensional examination of the international economic phenomena is not a truly sufficient framework for globalization (Harriss, 2002; Henry, 2005; Jacobs \& Frickel, 2009; Klein, 2006; Kleinberg, 2008; Schuurman, 2000; Sumner $\&$ Tribe, 2008; Weingart \& Padberg, 2014). Each fragmented approach or narrow thinking economic model used, which does not include or aim at a clear view of the underlying evolutionary synthesis, simply perpetuates myths and illusions regarding the real dynamics of globalization (Aglietta, 2008; Aglietta, 2010; Cohen, 2011; Servet, 2010).

If we are truly seeking to grasp the evolutionary shaping of globalization we need to think of it as a dialectic socio-economic phenomenon that forces a corresponding effort of dialectically perceiving it, since globalization is nothing less than an evolutionary road under a never-ending cycle of construction and reconstruction (B $\lambda \dot{\alpha} \delta \mathrm{\delta}$, 2006; B $\lambda \alpha \dot{\alpha} \delta o \varsigma, 2017)$.

1.1 The Contemporary Crisis of Globalization as a New Focal Point for Re-Orienting Research in Socio-Economic Sciences

The examination concerning the current crisis and the restructuring of globalization is now a critical theoretical field, crucial for the further development of all modern social sciences: from modern economics to political science (Chauprade, 2007; Fukuyama, 1992; Gauchon \& Huissoud, 2014; Huntington, 1997; Lacoste, 2012; 
Lacoste, 2014; Lévy, 2008; Strange, 1996) and from sociology (Colic-Peisker, 2010; Douki \& Minard, 2007; Dufoix, 2012; Grataloup, 2010; Graz, 2013; Heilbron, et al., 2009; Holton, 2008; Keck, 2010; King \& Le Galès, 2011; Lechner \& Boli, 2014; Martel, 2010; Mattelart, 2009a; Moore, 1966; Robertson et al., 2006; Rosenberg, 2005; Sassen, 2007; Simmons, et al., 2008; Selchow, Kaldor, \& Moore, 2012; Turner \& Holton, 2015; Warnier, 2010) to social psychology and cultural studies (Cardon \& Granjon, 2013; Duterme, 2014; Florida \& Boyett, 2002; Mattelart \& Neveu, 2008; Mattelart, 2009b; Noiriel, 2007).

In practice, an integrated study of innovation dynamics, of the current crisis and the restructuring process of globalization, now seems able to create a particularly fertile field of research (Aghion, et al., 2015; Brynjolfsson \& McAfee, 2015; Carlino \& Kerr, 2015; Gordon, 2017; OECD, 2014a; OECD, 2014b; OECD, 2015; Paunov \& Guellec, 2017).

\subsection{Towards a New Analytical Framework for Approaching the Ongoing Dynamics of Globalization}

In this direction and in an effort to overcome the deficiencies present when interpreting contemporary readjustments to global dynamics, there is a particular course to follow if one wishes to search for a new analytical framework. In particular, a counter-proposing method to this direction could be advanced in three consecutive stages.

- First stage is highlighting the living capitalist firm as the central, dialectic link between individual economic flows and movements of globalization.

- Second stage is clarifying the unbreakable, evolutionary interlacing between individual economic and broader social systems within globalization and therefore attributing the real interpretative weight in their unique history.

- Third stage is in finally looking into the underground interconnection between different national socio-economic systems and different sectorial dynamics which invariably traverse the edges of national borders and via their actions progressively unify the planet as a whole.

These distinct stages will guide this paper to further examine the particular schools of thought-which seem pretty fertile - in the new dialogue of the modern socio-economic sciences.

\subsection{For a New Theoretical Perspective Required to Understand the Current Global Dynamic}

A specific theoretical perspective required to conceive globalization should combine three successive "lenses".

- A lens for understanding globalization in economic terms with the capitalist firm at the center of the analysis

- A systemic lens to understand how globalization is structured in regards to socio-economic evolution.

- A spatially unifying lens to understand globalization through sectoral and cross-sectoral dynamics, because these are required in order to overcome the narrow explanatory powers of the national borders.

This new analytical perspective helps to understand in a different and novel way the problem of competitiveness within globalization (Acemoglu, et al., 2015; Acemoglu et al., 2016; Artus, et al., 2014; Bloom, et al., 2014). We could therefore perceive competitiveness as a result of dialectics, produced by the unceasing cross-fertilization of the following three dynamics: (a) the physiology of the firm, (b) the socio-economic space hosting the firm and (c) the surrounding sector of economic activity.

This repositioning of competitiveness' analysis, considered as crucial in our point of view, shows that the constant competitive claim of every socio-economic agent of action is the founding block of globalization.

Therefore, the key pursuit which is currently trending, competitiveness, could be said to be the very creator of globalization. And its evolutionary creation - the globalization dynamic - does not cease to define its creators dialectically and to delimit the actions of every agent of action (Annoni \& Kozovska, 2010; Crozet \& Lafourcade, 2010; Hidalgo \& Hausmann, 2009; Schwab, Sala i Martin \& World Economic Forum, 2016).

\section{Globalization as an Evolutionary Economic Process and the Living Capitalist Firm}

In the first step of this investigation we try to critically approach the analytical boundaries of the fragmented understanding of the various international economic flows (commercial, financial, migratory, productive, technological), by proposing a synthetic concept of globalization centered at the capitalistic enterprise. In our view, the contemporary capitalistic enterprise represents both the generator and the recipient of the global process.

The starting point for this theoretical orientation, requires enriching our analytical perspective and perceiving 
this capitalistic enterprise in a new evolutionary manner (Boyer \& Durand, 1998; Durand, 2000; Nelson, 2009; Prahalad \& Hamel, 2000; Torrès-Blay, 2000; Weinstein \& Azoulay, 2000).

In particular, we are going to achieve this by overpassing, the mechanistic, traditional neo-classical logic, in which the capitalistic enterprise is considered nothing more than a passive transformer of economic inflows into outflows and a static component of the price theory, supposedly operating as an automatic transaction mechanism of the "prescribed by the market" distribution of the production factors. This will be followed by bridging the ahistorical simplifications of the neo-Marxist approaches for which, usually, the capitalistic enterprise is nothing more than an unchangeable component of "exploitation as usual".

\subsection{What is a Capitalist Firm?}

To define the nature of the capitalist firm has never been an easy task, bearing unique or self-evident answers, as most of the traditional "introductions to microeconomics" textbooks imply (Cahuc, 1993; Hart, 1989; Hodgson, 1998; Holmstrom, 1999). The vast majority of such analyses introduce only the neoclassical theory of the firm, based on the works of L. Walras (Walras, 1874) and A. Marshall (Marshall, 1890), and rarely anything more than that.

In particular, the capitalist firm in the neoclassical tradition sense is built upon the following, extremely simplistic, assumptions:

* On achieving a steady equilibrium of perfect competition, perfect information and, most importantly, of a universally accessible and without costs level of technology.

* On the assumption of perfect rationality of all the economic agents who, continuously and exclusively, focus on maximizing their profits.

* On the analytical dominance of the market transactions over the dimension of production, where the firm operates simply as a receiver of prices or as a transaction mechanism for prescribed options.

However, in direct opposition to this restrictive belief, there is an increasing rate of research contributions which are specifically considered to be part of the broad thematic field of economics recognized by the title "Theory of the Firm" (Aoki, 1990; Coase, 2012; Ménard, 2012; Williamson, 1991), and which come to argue that, deep inside, we still do not really know enough about the core, the "central brain" of capitalism, nor do we have a complete scientific understanding of the dynamics of the capitalistic enterprise itself. In their essence, most of those new approaches to the capitalist firm (Arena \& Lazaric, 2003; Brousseau \& Glachant, 2002; Dosi \& Nelson, 1994) gradually converge around the acknowledgment of the firm's indivisible evolutionary nature. For them, the capitalist firm can only be, simultaneously:

a) A socio-economic organization: having a constant, dialectic aim of harmonizing and coordinating heterogeneously and endlessly conflicting interests and actions within it; conflicting interests of the ownership, the stakeholders, the lenders, the executives, the technicians, the permanent employees, the temporary staff.

b) A historical institution: which bears a specific historic, socio-economic content, evolving in both time and space.

c) An open systemic node: in constant co-determination and co-evolution with the external systemic environment.

d) And finally, a living organism: having internally physiological determinations and organic mechanisms to claim its survival and development within the changing environment.

Therefore, the firm as approached by a significant amount of the contemporary economic researchers, is quite justifiably no longer considered to be a hollow shell, a static black box that supposedly exists to simply perform an automatic transformation of economic inflows into outflows. On the contrary, the firm is now perceived, as a living, active participant and, in fact, as the fundamental structural co-creator of every sector of economic activity and of the socio-economic systems that host it (Williamson, 1999; Williamson, 2000; Williamson, 2002).

\subsection{The Gradual Reconstruction of the Analytical Simplifications Related to the Capitalist Firm}

The theory of the firm has been developing for about a century as an attempt to overturn the basic assumptions conceived by the neoclassical model. This attempt tries to utilize many parallel and sometimes intersected theoretical contributions.

Already by the 1930s, the first critical questions were founded regarding the competition model of the capitalistic market. The beginning was made with an important article by P. Sraffa (Sraffa, 1926) who criticized both the realism and the inner theoretical coherence of the perfect competition model and especially in regards to 
the partial balance as expressed in the "Marshallian version". The theory of imperfect competition by J. Robinson (Robinson, 1933) subsequently contributed decisively to a substantial renewal of the market and business microeconomics, by deepening the analysis into more complex, less perfect forms of competition, and which, in the long run, courageously moved much closer to the real economy. According to G.L.S. Shackle's work (Shackle, 1967), there was a constant demand throughout the development of the prewar Firm theory in an effort to shift the main interest from equilibrium theory (that of production conditions and the distribution of goods as presented by the neoclassical tradition), to the study of the entrepreneurial behavior and the interaction between the producers and the enterprises.

In particular, within the context of these critical contributions, there was a revival of the theoretical interest regarding the power of entrepreneurship and its critical role. In practice, although classical political economy, from A. Smith to J.B. Say and J.S. Mill, attributed to entrepreneurship and the person behind it-the entrepreneur - a central position when interpreting capitalistic functions, since the early $20^{\text {th }}$ century and with the then almost absolute domination of neoclassical thinking, the entrepreneur vanishes almost completely in the orthodox theory of economic science. However, the role of the entrepreneur and entrepreneurship in general cannot be discarded without consequences in regards to the interpretative capacity for any economic theory of capitalism. In the theoretical absence of entrepreneurship and its activity, namely the direct engine of thought and action of the capitalistic process, there are at least three crucial aspects that remain inevitably, completely obscure:

- Who and how is carrying out the operation of acquiring and utilizing information?

- Who and how is executing the operation of innovation and the creation of new action fields in capitalism?

- Who and how is undertaking the operation of organizing and coordinating production?

If there are no substantial answers to be given to these questions, then any approach to the capitalistic economy itself can only be superficial and, ultimately, short-sighted; doomed to end up in a repetitive and deadlocked interpretive routine. And therefore the evolutionary essence of the capitalistic process is omitted.

As a result, in order to gradually reconstruct all the fundamental neoclassical simplifications, toward a realistic understanding of the firm, among others, the following are required:

- An understanding that the capitalistic enterprise does not necessarily claim, at every step, the maximization of its profit; and even more, a profit which is narrowly expressed in monetary terms (Baumol, 1967). Either way, the overall strategic benefit extracted by a business can never be a narrow reflection of the money acquired. Furthermore, very often the profits are maximized over a period set by the firm beforehand. For example, for the most part, to increase its market share, to rapidly develop or/and to gradually weaken its competitors, but not to directly gain profits. And the firm's maximization of long-term profits can never be secured from a mere, constant claim of maximizing short-term profits.

* A disambiguation of the incomplete and asymmetric information, of the limited rationality of every economic agent and decision-maker, and of the constant uncertainty in the market (Simon, 1982). Information is neither complete nor free for every economic agent, nor does it come at no cost. All the "players" certainly do not have the same ability to process and absorb available information to the same extent.

* A closer examination of the deeper conflicting nature of relationships within and around the firm. At is core, a firm is set up, when the including interest groups form an alliance (Cyert \& March, 1963). The firm is in fact a place for balancing decision-making and for collective learning of roles and behaviors. Thus, it becomes clear that the very purpose of a business does not align, always and necessarily, with the interests of the ownership. For example, in addition, often but not always, the managerial class in large companies (Note 1) seeks to serve its own interests rather than those of the owner or of the business as a whole (Veblen, 1899).

- An underlining of the fact that seemingly similar businesses, as far as the same workforce composition and the same level of technology are concerned, very often end up with completely different results in terms of productivity, product quality and profitability. This is because they are characterized, at their core, by a different organizational quality (Note 2); the degree, namely, of efficiency maintained by individuals and firms under the conditions of imperfect competition. This is the point at which the importance of the organizational innovations, the transformations and the rises of the different business types within the developments of any socioeconomic system emerges (Chandler, 1962; Chandler, 1994).

In fact all the above-mentioned steps have become particularly important as the current crisis of globalization turned the outline of the capitalist firm even more fluid and the underlying dynamics even more complex. It seems that a "New Globalization" is gradually emerging. 
Accordingly, even more advanced approaches to analyze the capitalist firm are considered absolutely necessary.

\section{A "New Globalization" is Drastically Transforming the Environment for the Contemporary Capitalist Firm}

From the early 1980s to the present, the globalization dynamics, have spawned many upsets to concepts considered carved in stone in a capitalist economy. Nowadays, a "New Globalization" (Ahmad, 2013; Artus \& Virard, 2015; Bhattacharya, et al., 2017; Boyer, 2002; Bremmer, 2014; Brender \& Pisani, 2009; Dardot \& Laval, 2010; Dobbs, et al., 2015; Gordon, 2016; Peters, et al., 2011; Pieterse, 2011; Siles-Brügge, 2012; Wallerstein, 2012) seems to come into existence, evolving and settling as a new model for the global capitalist economy.

The global economy is now persistently tied to the ongoing economic crisis. This crisis that reshapes dynamically the context of the overall process of globalization and is the deeper cause of interpreting entrepreneurial dynamics under a new, evolutionary perspective.

\subsection{The Capitalist Firm as a Living System}

Based on a systemic approach the firm is perceived as a complex entity that performs three basic functions:

1. It draws productive inputs from the market of productive factors.

2. It transforms these inputs into outputs in order to generate profit by trying to attach some greater economic value to the outputs compared to the inserted inputs.

3. It distributes the outputs on the market of products where it raises revenue in order to remunerate the utilized productive factors and thus to generate, under certain conditions, profits for the entrepreneur: if the revenues are positive then there are profits, otherwise there are losses (de Rosnay, 2014; Forrester, 1984; von Bertalanffy, 1993).

For all of these entrepreneurial functions, the contemporary globalization dynamics have brought about and keep creating profound changes: it seems they are changing the very quality of the capitalist system and its rules (Drucker, 2006; Garratt, 2000; Hammer \& Champy, 1993; Handy, 1976; Landier, 1991; Linhart, 2010; Lynch \& Kordis, 1990; Nonaka \& Takeuchi, 1995; Peters, 1987; Pras \& Boutin, 1995; Quinn, 1992; Savage, 1996).

These ongoing dynamics of globalization are progressively and constantly transforming the very structure and nature of the modern capitalist firm. This kind of awareness shows the way for a living and evolutionary approach regarding the firm and its dynamics (Kogut \& Zander, 1992; Penrose, 1952; Provine, 1988; Smocovitis, 1992; Wiens, 2004): according to this view, when the external environment changes then every living organism ought to organically absorb these changes, to adapt — actively or passively - to the new reality.

This is also the case for the firm. Indeed, the deeper the environmental changes are, the more a surviving new organism will differ from its progenitor. And there are no superficial adaptations of this kind: a deeper metabolism and homeostasis (the metabolic equilibrium) for the new generation of the surviving organisms is, unavoidably, significantly different when compared to that of their ancestors' (Demeester, et al., 2002; Morgan, 1998). This is exactly the evolutionary process and transformation for the capitalist firms and the manner in which these unfold over the several spaces, on a global scale, by having an infinite variety and always differentiated architectures.

\subsection{The Stra.Tech.Man Physiology and the Innovation Dynamics of the Firm}

Consequently, under this evolutionary and living perspective there is also the Stra.Tech.Man approach which is structured upon (Vlados, 2005; Vlados \& Katimertzopoulos, 2017; Vlados, et al., 2018a; Vlados, et al., 2018b).

This interpretive point of view, a method for observing the evolutionary physiology of the living firm, is structured around a series of three subjective questions:

i. The strategic (Stra.) questions corresponds to "Where I am, where I plan on going, how I will get there and why?"

ii. The technological (Tech.) questions to "How do I draw, create, compose, diffuse and reproduce the means of my work and my expertise, and why?"

iii. And the managerial (Man.) questions to "How do I use my available resources and why?"

According to the Stra.Tech.Man perspective, these components define, continuously and dialectically, the unique, particular and ever-evolving dynamic triangle of strategy, technology and management for every business. An evolutionary triptych which characterizes, at its very root, a form of an evolutionary "DNA" for every kind of business and regardless of their size, their particular "species" and the hosting sector of economic activity. Every 
business, a particular socio-economic system in space and time, always builds a unique stra.tech.man triangle in order to effectively innovate and therefore generate profitability: there is always a Stra.Tech.Man business core in the background which is regulating the overall evolutionary course of the business. These three dynamics, when combined together, define the evolutionary physiology for every business.

The dynamic stra.tech.man triptych is always operating inside the business not only as a systemic receiver, but also as a high fidelity transformer of the overall socio-economic changes that globalization brings forth. We expect that all businesses, like any living organism, are changing according to the "planet's climate" and that, accordingly, the "globalization's climate" is changing because of those participating businesses and of the innovations that they encourage and work on.

Overall, we come to the conclusion that there is only one way for the contemporary business to competitively survive, regardless of its particular size, sectoral scope, spatial reach and unique physiology, which is an efficient innovative synthesis of Stra.Tech.Man terms (See figure 1).

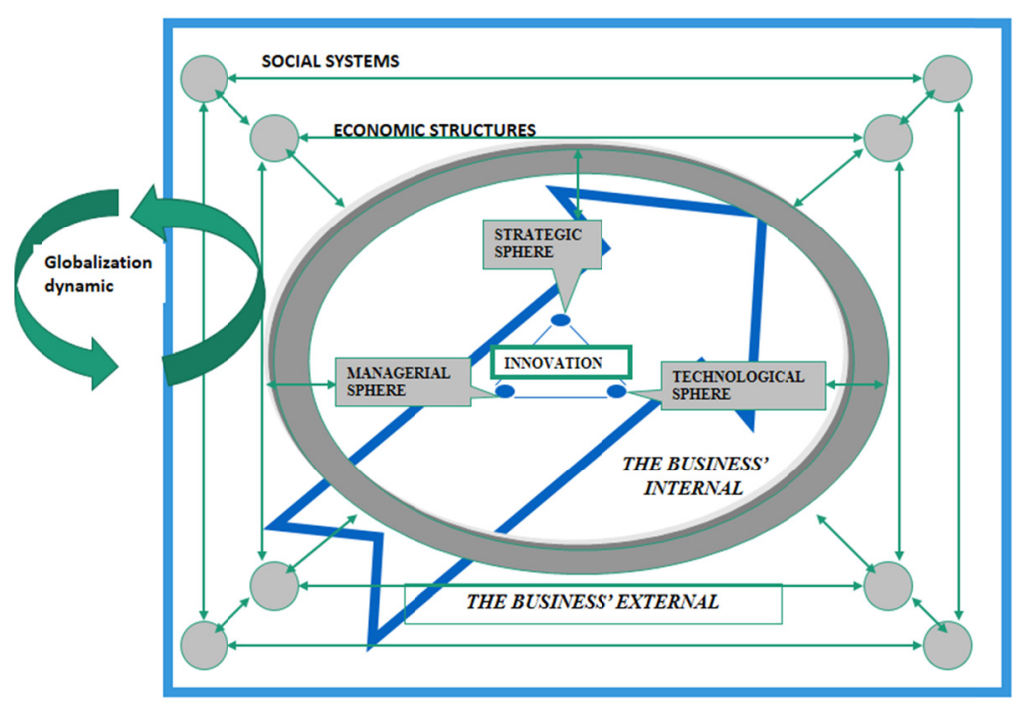

Figure 1. The innovation dialectics in Stra.Tech.Man terms inside the business physiology

In order for the synthesis of strategy, technology and management to prove practically effective there should be a cross-fertilizing of an internal and multi-faceted organizational dynamic according to the unique external environmental conditions and to the global dynamics where competitiveness - namely the survival and growth capacities - is defined as the syntheses of the businesses (and their unique physiologies), the sectors (and their dynamics) and the socio-economic spaces (and their particular historic evolutions) (See figure 2).

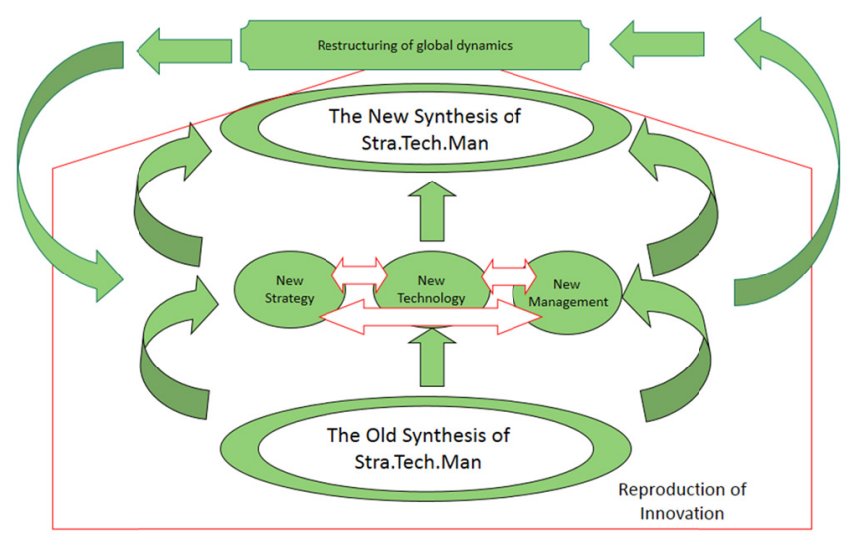

Figure 2. Reproduction of a firm's innovative potential in Stra.Tech.Man terms, within the globalization restructuring 
The innovation of the contemporary living business is finally a dialectic Stra.Tech.Man hypothesis: it is an evolutionary and physiological synthesis of strategy, technology and management. All the stra.tech.man spheres are following a trajectory defined by their particular reproducers: and every sphere is reborn in this synthesis. Thus, innovation is born from the unique firm's physiology. And within that dialectic stra.tech.man triangle of the business, the very regulator of globalization dynamics is also formed.

\section{The Firm at the Analytical Center of Evolutionarily Understanding Globalization}

With this kind of analytical basis in mind it is now possible to understand the capitalist firm as the cellular center of the globalization dynamics. The capitalist firm by itself (either of local, national or multi-national reach), for every variety of forms and actions, represents possibly the deepest analytical core to conceive-unifyingly and evolutionarily - the socio-economic content that the globalization and the current restructuring of globalization are carrying. And due to this, to the physiologically evolving firm being the source of global dynamics, the firm also receives at a structural level, the deep causes and effects of globalization.

Naturally, to this analytical direction, one must decidedly avoid a common illusion: there are no businesses acting autonomously, superior to the particular time and space and sector of economic activity. On the contrary, every firm is inescapably tied to the hosting external socio-economic environment. Actually, this evolving environment defines dynamically the firms' potentials to evolve and mutate itself and the environment.

\subsection{The Firm's Socio-Economic Environment, a Birth of an Unceasing Evolutionary Systemic Process}

A further examination of the structured depths of that external environment, regardless of spatial reach, can make it possible to recognize the three dialectical structures/actors which together form the environmental structural basis: (A) The particular institutional character of the spatially established socioeconomic system which absorbs all the activities (B) the businesses' activities structured internally and (C) the public/state intervention which contributes to the system's establishment and reproduction (See figure 3).

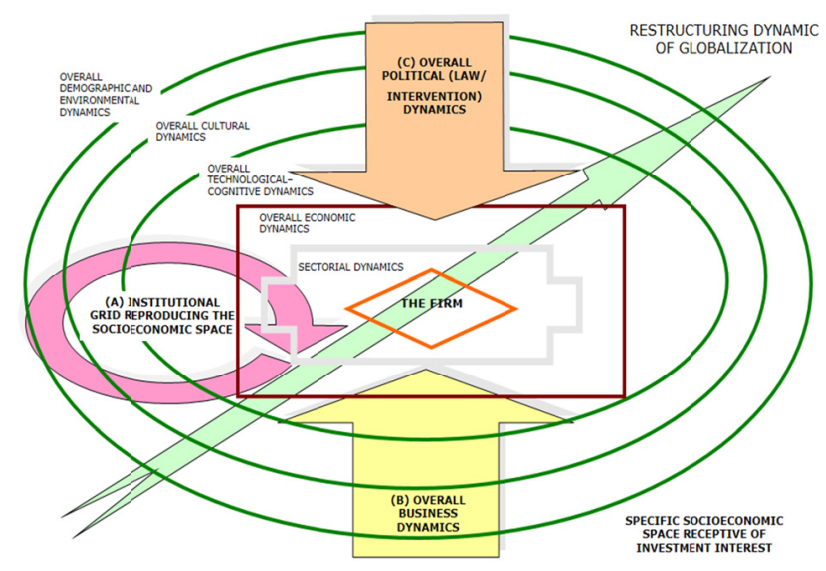

Figure 3. The broader external socioeconomic environment, an open evolutionary system

Every socioeconomic system is attached to a particular socioeconomic space which, apart from being the host for every economic activity, is also a "dialectical canvas" on which all the businesses' activities and the mechanisms for public intervention are drawn. On one hand, the individual entrepreneurial action and, on the other hand, the actions of collective intervention represent the two structural pillars which are constantly leveraging the reproduction system of the socioeconomic formations hosting the economic activities. And those constantly reshaped structural pillars acquire specific content and formation and define, simultaneously, the socioeconomic evolutionary trajectories.

The quantitative and qualitative dynamics of entrepreneurial investments are planted on a new socioeconomic field when filtered through the reasoning of public intervention. Ultimately, the hosting socioeconomic environment, by supplying specific kind of advantages or disadvantages, defines the successful sprouting of the "investment seed" and the possibility for a "new productive tree" to grow and survive: this always depends on the fertility rate of the "soil" that embraces the economic initiative.

And it is at this point exactly that the spatially established socioeconomic systems are acquiring significant 
importance, because they act as pools of advantages for the hosted entrepreneurial activity inside the constant race for survival and growth in globalization (Algan, et al., 2013; Amador \& Cabral, 2016; Arkolakis, et al., 2013; Bartelsman, et al., 2013; Chaney, 2016). More specifically, every spatially established socioeconomic system, regardless of its spatial reach, can be approached as a dialectical mechanism of four mutually dependent dynamic subsystems:

i. An economic subsystem engulfing the overall economic dynamic of the spatially established system.

ii. An economic subsystem embraced by the subsystem of social and productive knowledge uniquely defining every socioeconomic formation.

iii. A subsequent subsystem of the overall culture embraced by the subsystem of social knowledge.

iv. And, finally, a super-system of the natural and demographic environment embracing-always inescapably - all the structured socioeconomic subsystems.

The aforementioned set the basis for a theoretical perspective of explicit systemic character, governed by a simple founding principle: there is no use in understanding the economic dynamics - therefore the economics of development — outside of the, particular in space and time, broader historic and systemic socioeconomic context.

This kind of understanding gives us the chance to clarify the constant dynamic synthesis, which is at the root of all the evolutionary trajectories of globalization. Of the business actions, of the state interventions and of every spatially established socioeconomic system (Chiappini, 2014; Costinot \& Rodriguez-Clare, 2014; Daudin, et al., 2011; Fontagné, et al., 2013a). To recourse to the systematic examination of the evolutionary dynamics of the spatially established business - namely the "tree"-it provides particularly useful theoretical seeds to understand as well the evolutionary dynamics of the surrounding socioeconomic environment-say the "forest". An operating business of a particular socioeconomic, spatially established, system could be a theoretical start for understanding the unique explanatory content required to approach the broader phenomenon of development.

This explains our initial argument toward a need for a valid theoretical view of globalization in synthetic socioeconomic terms where the focus on the business is ubiquitous and closely tied to the broader social dynamics. This also helps to conceive the phenomenon of the overall socioeconomic development inside globalization: regarding every socioeconomic system and every spatial level of analysis.

Ultimately, all prior analyses serve to better realize the economic dynamics, as these are structured to the particular historic and social system and vice versa. In essence, there has never been an analytical separation between the economic and the broader phenomena of social development (Acemoglu \& Robinson, 2005; Acemoglu, 2008; Acemoglu \& Robinson, 2013).

\subsection{Sectoral and Cross-Sectoral Dynamics}

The living firm by itself represents the synthetic center of globalization dynamics. And this enterprise is never conceived independently of the surrounding, spatially established socioeconomic system. But how might we understand the interlacing of different socioeconomic systems within the globalization framework? What unifies them progressively? Is it market flows only? Is globalization only about the widening of global markets and nothing more than that?

No, of course not. The progressive unification of the various socioeconomic systems in globalization is much deeper. It traverses the surface and transforms the socioeconomic structures (Chang, 2006; Chavance, 2012; Crouch, 2005; Greif, 2006; North, 1994; North, et al., 2009; Ostrom \& Basurto, 2011; Rodrik, et al., 2004). It traverses the circulation of flows and the markets and penetrates the sphere of production (Balland, et al., 2015; Boschma, 2015; Brossard \& Moussa, 2014; Fontagné, et al., 2013b; Sölvell, et al., 2003). To this process, the role of the multinational enterprise has been critical for decades (Andreff, 2003; Delapierre \& Michalet, 1976; Delapierre, et al., 1983; Dunning \& Lundan, 2008; Michalet, 2002; Mucchielli \& Delapierre, 1995). Already from the 1970s, S. Hymer (Hymer, 1976; Hymer, 1982) argued toward this analytical direction, stating that the economic unification of the global system is due to the multinational firms and not to the global markets. The international markets are imperfect and the multinationals exploit the advantage of organizing the economic activities internally, therefore substituting the market with their internal arrangements. His approach, even though it offers unique insights, does not include all the aspects of these issues. And, most importantly, the approach omits the sectoral and cross-sectoral dimensions to the phenomenon of globalization.

Overall, the central sectoral element required for analysis is that of a coherent, systemic classification of business strategies that relate dynamically to the structures of production. A critical point to this sectoral analysis, also, is to clarify the inner evolutionary dynamics cultivated and produced in every sector of economic activity: when 
the evolutionary perspective is absent, when the sector is approached statically, then there is a certain lack of analytical soundness.

Exactly because of this lack of evolutionary perspective most of the "modern" approaches to the "sectoral dynamics" are constraining themselves to a repetitive and closed perception of things. They are mistaken in thinking of a sector of economic activity to be in autarky and sealed in a national operating framework, leaving globalization out of the equation. And yet, despite this scholarly myopia, some notable theorists have managed to provide useful insights to the opposite direction. Let us mention two fundamental of these.

* R. Vernon (Vernon, 1971; Vernon, 1992) was the first to argue that the transformations of the global economy are deriving from an irreversible tendency of sectoral movements from the more developed to the less developed nations. The principle reason for the sectoral relocations, according to him, were the product life cycles on a global scale.

* In turn, C. Palloix (Palloix, 1975) supported the idea that the multi-nationalization of the firms is due to a particular, deeper reality: the internationalization of capital and the three forms that is taking, not only as a capital-commodity and money-capital, but also, most importantly, as a productive capital.

For many years now, it has been proven that both these theorists were not mistaken into thinking of the internationalizations of the sectoral activities at the center. Despite the seemingly direct, "tangible", and progressive productive unification of the world due to the multinational enterprise, on the background those internationalizations are subject to the surrounding sectoral dynamics. There are no multinational or "national" business movements independent from the supranational sectoral dynamics which are involved and reproduced by these movements (Audretsch \& Lehmann, 2005; Breschi \& Lenzi, 2015; Hamel \& Prahalad, 1996; Piore, 1995; Porter, 1990; Porter, 2007; Ruigrok \& Van Tulder, 2013; Schumpeter, 1912; Schumpeter, 1939; Stopford, et al., 1991).

And nowadays, the restructuring and globalizing sectoral dynamics incorporate the various phenomena of the overall social restructuring by bringing forth a "new globalization" (Avant, et al., 2010; Awad, 2009; Baldwin \& Low, 2009; Breslin, 2016; Cottier \& Elsig, 2011; Palan, et al., 2013). And the globalizing sectors irreversibly unify the various socioeconomic formations on the planet, with respect to their economic, productive, and at the same time consumptive structures, and therefore restructuring the overall framework of globalization (See figure 4).

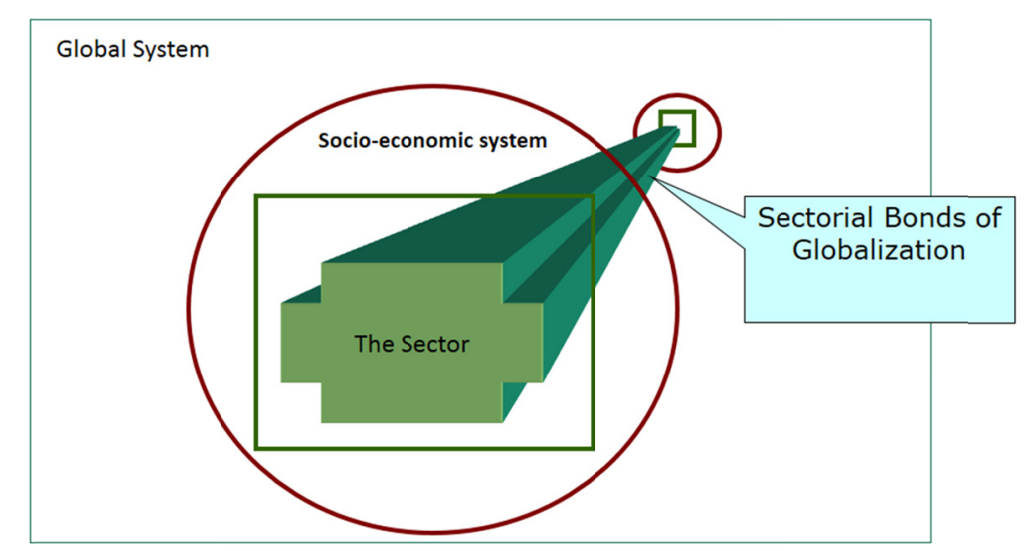

Figure 4. The sectors of economic activity are unifying the structural basis of the individual socioeconomic systems inside globalization

Accordingly, at every level, the broader socioeconomic space, is in a restructuring process within globalization. These sectoral, sub-sectoral and cross-sectoral supranational dynamics are in effect producing the backbone of this restructuring process of the various socioeconomic formations: the birth, the solidification, and the reproduction of that restructuring is due to the evolutionary intertwining of the "various industrial worlds" (Veltz, 2000) hosted in our planet.

And within that continuous, progressive globalization restructuring, that constantly reproduces tendencies of convergence and divergence, of homogeneity and heterogeneity, there emerges an acute question: how could someone initiate and maintain competitive advantages in this drastically changing world? 


\subsection{Global Competitiveness as a Synthesis of Business Dynamics, Socioeconomic Spaces and Sectoral Structures}

In general, competitiveness for the most part is simply referring to the ability to provide in the market (whether local, national or international) products and services in order to maintain some sort of effectiveness in the changing conditions of the international competitive environment. To manage therefore to sell, to profit and to grow within the globalized competition (Aghion, et al., 2011; Alfaro \& Charlton, 2013; Allomonte et al., 2016).

Such a definition is not wrong, but not very useful. An overly open definition of that kind sometimes misguides to different understandings and, most importantly, to highly divergent results (Best, 1990; Competitiveness Policy Council, 1995; Lado, et al., 1992; Scott \& Lodge, 1985). Therefore, some critical examinations that should otherwise be clear and unambiguous stay in the shadows.

- Which is the force that actually makes a socioeconomic subject competitive?

- Where in the process of the competitiveness synthesis is, the enterprise located specifically, where state intervention and where each particular socioeconomic formation?

- Where is the particular historical space and time that is structuring competitiveness?

In fact, it proves increasingly difficult for a definition of competitiveness to answer, validly and completely, these questions. And even worse, most often, the ambiguities which inevitably are generated lead to numerous hyper-simplifications and misunderstandings.

Actually, there is no simple and homogenous concept of competitiveness for a socioeconomic space regardless of the particular businesses operating within it, neither is there a simple and homogenous concept of competitiveness for a business regardless of the particular socioeconomic spaces where it establishes and conducts its operations. Competitiveness is never resulting, separately or isolated, only from one of these two spheres (Akcigit, et al., 2015; Bloom et al., 2012; Cadot, et al., 2011; Capaldo, 2015; Cheptea, et al., 2014; Hanson, et al., 2015; Hausmann, et al., 2014).

And this is because, in fact, there is no competitiveness for the socioeconomic space (of either local, regional or national reach), and neither is it possible to provide a valid definition of that competitiveness, when the particular businesses conducting their activities internally in that space and constantly influencing the evolutionary dynamics of that space are excluded. Accordingly, there is no such kind of competitiveness for the business that is outside that particular socioeconomic space hosting its actions. And, going even deeper, because both of these spheres (the socioeconomic space and the business) are "materializing" themselves - always dialectically - to particular sectoral/cross-sectoral productive systems, which traverse the typical local, national and regional administrative frontiers, the surrounding sectoral and cross-sectoral supra-national dynamics are always present.

So, in particular, real competitiveness may only be the dialectic synthesis between the business and the socioeconomic space of action and the expression deriving from the sectoral dynamics that define competitiveness as a dynamic whole. In reality, only the hosting socioeconomic space and the operating internally of that space businesses create and synthesize, at the same time, the competitiveness which takes shape always within a particular historic framework of productive and sectoral structures and dynamics. These three dynamics, always tied to each other, give birth to competitiveness. The dialectic synthesis of these gives birth and reproduces competitiveness. The socioeconomic space, the businesses and the sector of productive activity represent the dynamic whole, the basis for every reliable study to competitiveness and, therefore, for the very phenomenon of development inside globalization (See figure 5).

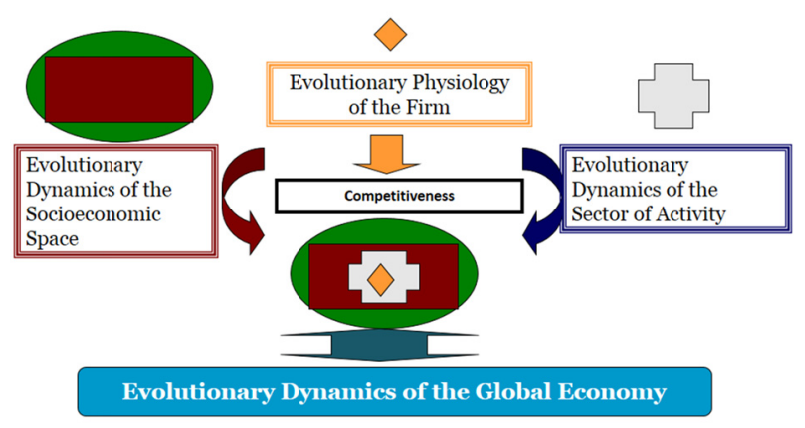

Figure 5. Contemporary economy creates and reproduces the competitiveness in globalization inside an unbreakable, evolutionary nexus 


\section{Concluding remarks: The Need for a New Organic-Strategic Understanding of Competitiveness in the Phase of Globalization}

According to the above, it is clear now why the approach to the question of competitiveness in globalization is repositioning and restructuring, both directly and indirectly, all the theoretical and practical applications of the contemporary economic science. It is of critical importance to understand the process of competitiveness evolutionarily because it provides a truly reliable compass to traverse and realize the inner coherence of the globalization dynamic.

Over this understanding, a new and valid horizon of methodologies which can be used to approach the broader phenomenon of development lays ahead: A) a new cross-entrepreneurial, B) a new cross-spatial and C) a new cross-sectoral.

I. The competitiveness for every business is the dialectic collection of different competitivenesses, collected from distinct pairs of spaces and productive sectors in which they are participating.

II. In parallel, a competitiveness for a socioeconomic space is the dialectic collection of different competitivenesses, structured around the internal businesses and the distinct productive sectors.

III. And, finally, the competitiveness for a complete productive sector is the dialectic collection of the produced competitivenesses internally of the sector and in terms of particular pairs of businesses and socioeconomic spaces hosting the business actions.

Having the previous analysis in mind we support, therefore, that these three dimensions constitute the basis for every new and valid developmental analysis or intervention within the ongoing phase of crisis and the restructuring process of globalization.

All these together form a complete and a comprehensive view of the ever unique in history phenomenon of development.

\section{References}

Acemoglu, D. (2008). Introduction to modern economic growth. Princeton University Press.

Acemoglu, D., \& Robinson, J. A. (2005). Economic origins of dictatorship and democracy. Cambridge University Press. https://doi.org/10.1017/CBO9780511510809

Acemoglu, D., \& Robinson, J. A. (2013). Why nations fail: The origins of power, prosperity, and poverty. Broadway Business.

Acemoglu, D., Autor, D., Dorn, D., Hanson, G. H., \& Price, B. (2016). Import competition and the great US employment sag of the 2000s. Journal of Labor Economics, 34(S1), S141-S198. https://doi.org/10.1086/682384

Acemoglu, D., Gancia, G., \& Zilibotti, F. (2015). Offshoring and directed technical change. American Economic Journal: Macroeconomics, 7(3), 84-122. https://doi.org/10.1257/mac.20130302

Aghion, P., Akcigit, U., Bergeaud, A., Blundell, R., \& Hémous, D. (2015). Innovation and top income inequality (No. w21247). National Bureau of Economic Research. https://doi.org/10.3386/w21247

Aghion, P., Boulanger, J., \& Cohen, E. (2011). Rethinking industrial policy (No. 2011/04). Brussels: Bruegel.

Aglietta, M. (2008). La crise: Pourquoi en est-on arrivé là? Comment en sortir? Paris: Michalon.

Aglietta, M. (2010). La crise: Les voies de sortie. Paris: Michalon.

Ahmad, A. (2013). New age globalization: Meaning and metaphors. https://doi.org/10.1057/9781137319494

Akcigit, U., Baslandze, S., \& Stantcheva, S. (2016). Taxation and the international mobility of inventors. American Economic Review, 106(10), 2930-81. https://doi.org/10.1257/aer.20150237

Alfaro, L., \& Charlton, A. (2013). Growth and the quality of foreign direct investment. In Yifu, J. L. The industrial policy revolution I: The role of government beyond ideology (pp. 162-204). https://doi.org/10.1057/9781137335173_12

Algan, Y., Cahuc, P., \& Shleifer, A. (2013). Teaching practices and social capital. American Economic Journal: Applied Economics, 5(3), 189-210. https://doi.org/10.1257/app.5.3.189

Altomonte, C., Bas, M., Bugamelli, M., Colantone, I., Fontagné, L., Forlani, E., ... \& Ottaviano, G. I. (2016). Measuring competitiveness in Europe: Resource allocation, granularity and trade. Brussels: Bruegel Blueprint Series Volume XVIV. 
Amador, J., \& Cabral, S. (2016). Global value chains: A survey of drivers and measures. Journal of Economic Surveys, 30(2), 278-301. https://doi.org/10.1111/joes.12097

Andreff, W. (2003). Les multinationales globales. Paris: La Découverte.

Annoni, P., \& Kozovska, K. (2010). EU regional competitiveness index. Luxemburg: European Comission, Joint Research Centre.

Aoki, M. (1990). The firm as a nexus of treaties. London: Sage Publications.

Arena, R., \& Lazaric, N. (2003). La théorie évolutionniste du changement économique de Nelson et Winter. Revue économique, 54(2), 329-354. https://doi.org/10.3917/reco.542.0329

Arkolakis, C., Ramondo, N., Rodríguez-Clare, A., \& Yeaple, S. (2013). Innovation and production in the global economy (No. w18972). National Bureau of Economic Research. https://doi.org/10.3386/w18972

Artus, P., \& Virard, M.-P. (2015). Croissance zéro, comment éviter le chaos? Paris: Fayard.

Artus, P., García-Peñalosa, C., \& Mohnen, P. (2014). Redresser la croissance potentielle de la France. Notes du conseil d'analyse économique, (6), 1-12. https://doi.org/10.3917/ncae.016.0001

Audretsch, D. B., \& Lehmann, E. E. (2005). Does the knowledge spillover theory of entrepreneurship hold for regions? Research Policy, 34(8), 1191-1202. https://doi.org/10.1016/j.respol.2005.03.012

Avant, D. D., Finnemore, M., \& Sell, S. K. (Eds.). (2010). Who governs the globe? (Vol. 114). Cambridge University Press. https://doi.org/10.1017/CBO9780511845369

Awad, I. (2009). The global economic crisis and migrant workers. ILO.

Baldwin, R., \& Low, P. (Eds.). (2009). Multilateralizing regionalism: Challenges for the global trading system. Cambridge University Press. https://doi.org/10.1017/CBO9781139162111

Balland, P. A., Boschma, R., \& Frenken, K. (2015). Proximity and innovation: From statics to dynamics. Regional Studies, 49(6), 907-920. https://doi.org/10.1080/00343404.2014.883598

Bartelsman, E., Haltiwanger, J., \& Scarpetta, S. (2013). Cross-country differences in productivity: The role of allocation and selection. American Economic Review, 103(1), 305-34. https://doi.org/10.1257/aer.103.1.305

Baumol, W. J. (1967). Business behavior, value and growth. San Diego, CA: Harcourt, Brace \& World.

Best, M. H. (1990). The new competition: Institutions of industrial restructuring. Cambridge, MA: Harvard University Press.

Bhattacharya, A., Khanna, D., Schweizer, C., \& Bijapurkar, A. (2017, April 25). The New Globalization: Going Beyond the Rhetoric. BCG Henderson Institute. Retrieved March 19, 2018, from https://www.bcg.com/publications/2017/new-globalization-going-beyond-rhetoric.aspx

Bloom, N., Romer, P. M., Terry, S. J., \& Van Reenen, J. (2014). Trapped factors and China's impact on global growth (No. w19951). National Bureau of Economic Research. https://doi.org/10.3386/w19951

Bloom, N., Sadun, R., \& Van Reenen, J. (2012). The organization of firms across countries. The quarterly journal of economics, 127(4), 1663-1705. https://doi.org/10.1093/qje/qje029

Boschma, R. (2015). Towards an evolutionary perspective on regional resilience. Regional Studies, 49(5), 733-751. https://doi.org/10.1080/00343404.2014.959481

Boyer, R. (2002). La croissance, début de siècle. De l'octet au gène. Paris: Bibliothèque Albin Michel Économie.

Boyer, R., \& Durand, J. P. (1998). L'après-fordisme. Paris: Syros.

Bremmer, I. (2014). The New Rules of Globalization. Harvard Business Review, 92(1), 103-107.

Brender, A., \& Pisani, F. (2009). La crise de la finance globalisée. Paris: La Découverte.

Breschi, S., \& Lenzi, C. (2015). The role of external linkages and gatekeepers for the renewal and expansion of US cities' knowledge base, 1990-2004. Regional Studies, 49(5), $782-797$. https://doi.org/10.1080/00343404.2014.954534

Breslin, S. (2016). China and the global political economy. London: Springer.

Brossard, O., \& Moussa, I. (2014). The French cluster policy put to the test with differences-in-differences estimates. Economics Bulletin, 34(1), 520-529. 
Brousseau, E., \& Glachant, J. M. (Eds.). (2002). The economics of contracts: Theories and applications. Cambridge University Press. https://doi.org/10.1017/CBO9780511613807

Brynjolfsson, E., \& McAfee, A. (2015). Le deuxième âge de la machine: travail et prospérité à l'heure de la révolution technologique. Odile Jacob.

Cadot, O., Carrère, C., \& Strauss-Kahn, V. (2011). Export diversification: What's behind the hump? Review of Economics and Statistics, 93(2), 590-605. https://doi.org/10.1162/REST_a_00078

Cahuc, P. (1993). La nouvelle microéconomie. Paris: La Découverte.

Capaldo, J. (2015). The trans-atlantic trade and investment partnership: European disintegration, unemployment and instability. Economia \& lavoro, 49(2), 35-56.

Cardon, D., \& Granjon, F. (2013). Médiactivistes. Paris: Les Presses de Sciences Po.

Carlino, G., \& Kerr, W. R. (2015). Agglomeration and innovation. In Handbook of regional and urban economics (Vol. 5, pp. 349-404). Elsevier. https://doi.org/10.1016/B978-0-444-59517-1.00006-4

Chandler, A. D. (1962). Strategy and structure: Chapters in the history of the industrial enterprise. Cambridge, MA: MIT press.

Chandler, A. D. (1994). Scale and scope: The dynamics of industrial capitalism. Cambridge, MA and London: Harvard University Press.

Chaney, T. (2016). Networks in international trade. In Oxford Handbook of the Economics of Networks (pp. 754-775). Oxford: Oxford University Press.

Chang, H. J. (2006). Understanding the relationship between institutions and economic development. Some key theoretical issues. Revista de Economía Institucional, 8(14), 125-136.

Chauprade, A. (2007). Géopolitique: Constantes et changements dans l'histoire. Paris: Ellipses.

Chavance, B. (2012). John Commons's organizational theory of institutions: a discussion. Journal of Institutional Economics, 8(1), 27-47. https://doi.org/10.1017/S1744137411000336

Cheptea, A., Fontagné, L., \& Zignago, S. (2014). European export performance. Review of World Economics, 150(1), 25-58. https://doi.org/10.1007/s10290-013-0176-Z

Chiappini, R. (2014). Persistence vs. mobility in industrial and technological specialisations: Evidence from 11 Euro area countries. Journal of Evolutionary Economics, 24(1), 159-187. https://doi.org/10.1007/s00191-013-0331-7

Coase, R. H. (2012). The firm, the market, and the law. Chicago and London: University of Chicago press.

Cohen, D. (2011). La Mondialisation et ses ennemis. Paris: Pluriel.

Colic-Peisker, V. (2010). Free floating in the cosmopolis? Exploring the identity-belonging of transnational knowledge workers. 10(4), 467-488. https://doi.org/10.1111/j.1471-0374.2010.00298.x

Competitiveness Policy Council. (1995). Saving more and investing better: A strategy for securing prosperity. Washington, DC: Fourth Report to the President and Congress (US Government Printing Office).

Costinot, A., \& Rodríguez-Clare, A. (2014). Trade theory with numbers: Quantifying the consequences of globalization. In Handbook of international economics (Vol. 4, pp. 197-261). Amsterdam: Elsevier. https://doi.org/10.1016/B978-0-444-54314-1.00004-5

Cottier, T., \& Elsig, M. (Eds.). (2011). Governing the World Trade Organization: Past, present and beyond Doha. Cambridge University Press. https://doi.org/10.1017/CBO9780511792502

Crouch, C. (2005). Capitalist diversity and change: Recombinant governance and institutional entrepreneurs. Oxford: OUP. https://doi.org/10.1093/acprof:oso/9780199286652.001.0001

Crozet, M., \& Lafourcade, M. (2010). La nouvelle économie géographique. Paris: La Découverte.

Cyert, R. M., \& March, J. G. (1963). A behavioral theory of the firm. New Jersey: Prentice-Hall.

Dardot, P., \& Laval, C. (2010). La nouvelle raison du monde. Paris: La Découverte.

Daudin, G., Rifflart, C., \& Schweisguth, D. (2011). Who produces for whom in the world economy? Canadian Journal of Economics/Revue canadienne d'économique, 44(4), 1403-1437. https://doi.org/10.1111/j.1540-5982.2011.01679.x

de Rosnay, J. (2014). Le Macroscope: Vers une vision globale. Paris: Points. 
Delapierre, M., \& Michalet, C.-A. (1976). Les implantations étrangères en France: Stratégies et structures. Paris: Calmann-Lévy.

Delapierre, M., Madeuf, B., Michalet, C. A., \& Ominami, C. (1983). Nationalisations et internationalisation. Paris: Maspero.

Demeester, L., Eichler, K., \& Loch, C. (2002). What the biological cell can teach us about the future of manufacturing. Insead Working Paper Series.

Dobbs, R., Lund, S., Woetzel, J., \& Mutafchieva, M. (2015). Debt and (not much) deleveraging. McKinsey Global Institute, 136.

Dosi, G., \& Nelson, R. R. (1994). An introduction to evolutionary theories in economics. Journal of evolutionary economics, 4(3), 153-172. https://doi.org/10.1007/BF01236366

Douki, C., \& Minard, P. (2007). Histoire globale, histoires connectées: Un changement d'échelle historiographique? Revue d'Histoire Moderne et Contemporaine, 5(54-4bis), 7-21. https://doi.org/10.3917/rhmc.545.0007

Drucker, P. F. (2006). Innovation and Entrepreneurship (Reprint edition). New York: HarperBusiness.

Dufoix, S. (2012). La dispersion: Une histoire des usages du mot diaspora. Paris: Editions Amsterdam.

Dunning, J. H., \& Lundan, S. M. (2008). Multinational enterprises and the global economy. (Second Edition) Cheltenham, UK and Northampton, MA, USA: Edward Elgar Publishing.

Durand, R. (2000). Entreprise et évolution économique. Paris: Belin.

Duterme, B. (2014). La Rébellion qui dure: Points de vue du Sud. Paris: Syllepse.

Florida, R., \& Boyett, M. (2002). The rise of the creative class: And How it's transforming work, leisure, community, and everyday life. New York: Basic Books.

Fontagné, L., Gourdon, J., \& Jean, S. (2013a). Transatlantic trade: whither partnership, which economic consequences? CEPII Policy Brief, 1, 10.

Fontagné, L., Koenig, P., Mayneris, F., \& Poncet, S. (2013b). Cluster policies and firm selection: Evidence from France. Journal of regional science, 53(5), 897-922. https://doi.org/10.1111/jors.12050

Forrester, J. W. (1984). Principes des systèmes. Lyon: Presses Universitaires de Lyon.

Fukuyama, F. (1992). The end of history and the last man. New York: Free Press.

Galbraith, J. K. (1967). The New Industrial State. Princeton and Oxford: Princeton University Press.

Garratt, B. (2000). The learning organization: Developing democracy at work. New York: HarperCollinsBusiness.

Gauchon, P., \& Huissoud, J. M. (2014). Les maîtres du monde. Que sais-je?, 3, 29-50.

Gordon, R. J. (2016, February 20). L'âge d'or de la croissance est derrière nous. Le Monde Économie. Retrieved March 6, 2018, from http://www.lemonde.fr/economie/article/2016/02/20/robert-j-gordon-l-age-d-or-de-la-croissance-est-derrier e-nous_4868845_3234.html

Gordon, R. J. (2017). The rise and fall of American growth: The US standard of living since the civil war. Princeton University Press.

Grataloup, C. (2010). Géohistoire de la mondialisation: Le temps long du monde. Paris: Armand Colin.

Graz, J.-C. (2013). La gouvernance de la mondialisation. Paris: La Découverte.

Greif, A. (2006). Institutions and the path to the modern economy: Lessons from medieval trade. Cambridge: Cambridge University Press. https://doi.org/10.1017/CBO9780511791307

Hamel, G., \& Prahalad, C. K. (1996). Competing for the future. Brighton, MA: Harvard Business Press.

Hammer, M., \& Champy, J. (1993). Reengineering the corporation. A manifesto for business revolution. New York: Harper.

Handy, C. (1976). Understanding organizations. Oxford: Oxford University Press.

Hanson, G. H., Lind, N., \& Muendler, M. A. (2015). The dynamics of comparative advantage (No. w21753). National bureau of economic research. https://doi.org/10.3386/w21753 
Harriss, J. (2002). The case for cross-disciplinary approaches in international development. World Development, 30(3), 487-496. https://doi.org/10.1016/S0305-750X(01)00115-2

Hart, O. (1989). An economist's perspective on the Theory of the firm. Columbia Law Review, 89(7), 1757-1774. https://doi.org/10.2307/1122818

Hausmann, R., Hidalgo, C. A., Bustos, S., Coscia, M., Simoes, A., \& Yildirim, M. A. (2014). The atlas of economic complexity: Mapping paths to prosperity. Cambridge: MIT Press.

Heilbron, J., Guilhot, N., \& Jeanpierre, 1. (2009). Vers une histoire transnationale des sciences sociales. Sociétés Contemporaines, 1(73), 121-145. https://doi.org/10.3917/soco.073.0121

Henry, S. (2005). Disciplinary hegemony meets interdisciplinary ascendancy: Can interdisciplinary/integrative studies survive, and, if so, how. Issues in Integrative Studies, 23, 1-37.

Hidalgo, C. A., \& Hausmann, R. (2009). The building blocks of economic complexity. Proceedings of the National Academy of Sciences 106.26, 10570-10575. https://doi.org/10.1073/pnas.0900943106

Hodgson, G. M. (1998). Competence and contract in the theory of the firm. Journal of Economic Behavior \& Organization, 35(2), 179-201. https://doi.org/10.1016/S0167-2681(98)00053-5

Holmstrom, B. (1999). The firm as a subeconomy. Journal of Law, Economics, and Organization, 15(1), 74-102. https://doi.org/10.1093/jleo/15.1.74

Holton, R. J. (2008). Global networks. New York: Palgrave Macmillan.

Huntington, S. P. (1997). The clash of civiliztaions. New York: Simon \& Schuster.

Hymer, S. (1976). The international operations of national firms: A study of direct foreign investment. Cambridge, MA: MIT Press.

Hymer, S. (1982). The multinational corporation and the law of uneven development. In Hymer, S. International economics policies and their Theoretical foundations, ( https://doi.org/10.1016/B978-0-12-444280-1.50021-5

Jacobs, J. A., \& Frickel, S. (2009). Interdisciplinarity: A critical assessment. Annual Review of Sociology, 35, 43-65. https://doi.org/10.1146/annurev-soc-070308-115954

Keck, F. (2010). Un monde grippé. Paris: Flammarion.

King, D., \& Le Galès, P. (2011). Sociologie de l'État en recomposition. Revue Française de Sociologie, 52, 453-480. https://doi.org/10.3917/rfs.523.0453

Klein, J. T. (2006). Resources for interdisciplinary studies. Change: The Magazine of Higher Learning, 38(2), 50-56. https://doi.org/10.3200/CHNG.38.2.50-56

Kleinberg, E. (2008). Interdisciplinary studies at a crossroads. Division I Faculty Publications, 99. Retrieved from https://wesscholar.wesleyan.edu/div1 facpubs/99

Kogut, B., \& Zander, U. (1992). Knowledge of the firm, combinative capabilities, and the replication of technology. Organization science, 3(3), 383-397. https://doi.org/10.1287/orsc.3.3.383

Lacoste, Y. (2012). Géopolitique: La longue histoire d'aujourd'hui. Paris: Larousse.

Lacoste, Y. (2014). La géographie, ça sert, d'abord, à faire la guerre. Paris: La Découverte.

Lado, A. A., Boyd, N. G., \& Wright, P. (1992). A competency-based model of sustainable competitive advantage: Toward a conceptual integration. Journal of Management, 18(1), 77-91. https://doi.org/10.1177/014920639201800106

Landier, H. (1991). Vers l'entreprise intelligente: Dynamique du changement et mutation du management. Paris: Calmann-Lévy.

Lechner, F. J., \& Boli, J. (2014). The globalization reader (Fifth Edition). West Sussex, UK: Wiley-Blackwell.

Leibenstein, H. (1987). Inside the firm: The inefficiencies of hierarchy. https://doi.org/10.4159/harvard.9780674420809

Lévy, J. (ed.). (2008). L'invention du monde: Une géographie de la mondialisation. Paris: Les Presses de Sciences Po.

Linhart, D. (2010). La modernisation des entreprises. Paris: La Découverte. 
Lynch, D., \& Kordis, P. L. (1990). Strategy of the dolphin: Scoring a win in a chaotic world. New York: Fawcett.

Marshall, A. (1890). Principles of political economy. New York: Maxmillan.

Martel, F. (2010). Mainstream. Enquête sur cette culture qui plâ̂t à tout le monde. Paris: Flammarion.

Mattelart, A. (2009a). Diversité culturelle et mondialisation. Paris: La Découverte.

Mattelart, A. (2009b). Histoire de la société de l'information. Paris: La Découverte.

Mattelart, A., \& Neveu, E. (2008). Introduction aux cultural studies. Paris: La Découverte.

Ménard, C. (2012). L'économie des organisations. Paris: La découverte.

Michalet, C.-A. (2002). Qu'est-ce que la mondialisation. Paris: La Découverte.

Moore, W. E. (1966). Global sociology: The world as a singular system. American Journal of Sociology, 71(5), 475-482. https://doi.org/10.1086/224165

Morgan, G. (1998). Reading and shaping organizational life. Images of organization: The executive edition. Oakland, USA: Berrett-Koehler Publishers

Mucchielli, J.-L., \& Delapierre, M. (1995). Multinationales et mondialisation. Paris: Vuibert.

Nelson, R. R. (2009). An evolutionary theory of economic change. Cambridge, MA and London, UK: The Belknap Press of Harvard University Press.

Noiriel, G. (2007). A quoi sert "l'identité nationale"? Marseille: Agone.

Nonaka, I., \& Takeuchi, H. (1995). The knowledge-creating company: How Japanese companies create the dynamics of innovation. New York and Oxford: Oxford University Press.

North, D. C. (1994). Economic performance through time. The American economic review, 84(3), 359-368.

North, D. C., Wallis, J. J., \& Weingast, B. R. (2009). Violence and social orders: A conceptual framework for interpreting recorded human history. Cambridge/New York: Cambridge University Press. https://doi.org/10.1017/CBO9780511575839

OECD (2014a). Examens des politiques d'innovation. Paris

OECD (2014b). New sources of growth: knowledge-based capital. Paris

OECD (2015). Manuel de Frascati. Paris

Ostrom, E., \& Basurto, X. (2011). Crafting analytical tools to study institutional change. Journal of institutional economics, 7(3), 317-343. https://doi.org/10.1017/S1744137410000305

Palan, R., Murphy, R., \& Chavagneux, C. (2013). Tax havens: How globalization really works. Cornell University Press.

Palloix, C. (1975). L'internationalisation du capital: Eléments critiques. (Vol. 23). Paris: François Maspero.

Paunov, C., \& Guellec, D. (2017). Digital innovation and the distribution of income. Measuring and accounting for innovation in the 21st century, NBER, Book Series in Income and Wealth.

Penrose, E. T. (1952). Biological analogies in the theory of the firm. The American Economic Review, 42(5), 904-819. Retrieved from http://www.jstor.org/stable/1812528

Peters, B., Pierre, J., \& Randma-Liiv, T. (2011). Global Financial Crisis, Public Administration and Governance: Do New Problems Require New Solutions? Public Organization Review, 11(1), 13-27. https://doi.org/10.1007/s11115-010-0148-x

Peters, T. J. (1987). Thriving on chaos: Handbook for a management revolution. New York: Harper and Row.

Pieterse, J. N. (2011). Global Rebalancing: Crisis and the East-South Turn. Development and Change, 42, 22-48. https://doi.org/10.1111/j.1467-7660.2010.01686.x

Piore, M. J. (1995). Beyond individualism. Cambridge, MA: Harvard University Press.

Porter, M. E. (1990). The Competitive Advantage of Nations. New York: Free Press. https://doi.org/10.1007/978-1-349-11336-1

Porter, M. E. (2007). Clusters and economic policy: Aligning public policy with the new economics of competition. White Paper (Institute for Strategy and Competitiveness, Harvard Business School). 
Prahalad, C. K., \& Hamel, G. (2000). The core competence of the corporation. Strategic learning in a knowledge economy, (pp. 3-22). https://doi.org/10.1016/B978-0-7506-7223-8.50003-4

Pras, B., \& Boutin, A. (1995). Les Euro-PMI. Paris: Économica. https://halshs.archives-ouvertes.fr/halshs-00150669

Provine, W. B. (1988). Progress in evolution and meaning in life. Evolutionary Progress, 49-74.

Quinn, J. B. (1992). The intelligent enterprise a new paradigm. The Executive, 6(4), 48-63. https://doi.org/10.5465/AME.1992.4274474

Robertson, R., Scholte, J. A., Cheru, F., Chinkin, C., Conca, K., Holton, R., ... \& Ning, W (2006). Encyclopedia of globalization. New York: Routledge.

Robinson, J. (1933). The economics of imperfect competition. London: Macmillan.

Rodrik, D., Subramanian, A., \& Trebbi, F. (2004). Institutions rule: The primacy of institutions over geography and integration in economic development. Journal of Economic Growth, 9(2), 131-165. https://doi.org/10.1023/B:JOEG.0000031425.72248.85

Rosenberg, J. (2005). Globalization theory: A post mortem. International Politics, 42, 2-74. https://doi.org/10.1057/palgrave.ip.8800098

Ruigrok, W., \& Van Tulder, R. (2013). The logic of international restructuring: The management of dependencies in rival industrial complexes. London and New York: Routledge.

Sassen, S. (2007). A sociology of globalization. New York: W. W. Norton \& Company.

Savage, C. M. (1996). Fifth generation management: Co-creating through virtual enterprising, dynamic teaming, and knowledge networking (Revised Edition). Boston: Butterworth-Heinemann.

Schumpeter, J. (1912). Theory of Economic Development. New York: Oxford University Press.

Schumpeter, J. A. (1939). Business cycles. New York: McGraw-Hill.

Schuurman, F. J. (2000). Paradigms lost, paradigms regained? Development studies in the twenty-first century. Third World Quarterly, 21, 7-20. https://doi.org/10.1080/01436590013198

Schwab, K., Sala i Martin, X., \& World Economic Forum. (2016). The Global Competitiveness Report 2016-2017. Geneva: World Economic Forum.

Scott, B. R., \& Lodge, G. C. (1985). US competitiveness in the world economy. Thunderbird International Business Review, 27(1), 26-26. https://doi.org/10.1002/tie.5060270112

Selchow, S., Kaldor, M., \& Moore, H. L. (2012). Global civil society 2012: Ten years of critical reflection.. https://doi.org/10.1057/9780230369436

Servet, J.-M. (2010). Le grand renversement: De la crise au renouveau solidaire. Paris: Desclée De Brouwer.

Shackle, G. (1967). The years of high theory: Invention and tradition in economic thought 1926-1939. Cambridge, UK: Cambridge University Press.

Siles-Brügge, G. (2012). Europe and the management of globalization. Political Studies Review, 10(1), 151. https://doi.org/10.1111/j.1478-9302.2011.00255_7.x

Simmons, B., Dobbin, F., \& Garrett, G. (2008). The global diffusion of markets and democracy. https://doi.org/10.1017/CBO9780511755941

Simon, H. A. (1982). Models of bounded rationality: Empirically grounded economic reason (Vol. 3). Cambridge, MA: MIT press.

Smocovitis, V. B. (1992). Unifying biology: The evolutionary synthesis and evolutionary biology. Journal of the History of Biology, 25(1), 1-65. https://doi.org/10.1007/BF01947504

Sölvell, Ö., Lindqvist, G., \& Ketels, C. (2003). The cluster initiative greenbook. Stockholm: Ivory Tower Publishers.

Sraffa, P. (1926). The laws of returns under competitive condition. The Economic Journal, 36(144), 535-550. https://doi.org/10.2307/2959866

Stopford, J. M., Strange, S., \& Henley, J. S. (1991). Rival states, rival firms: Competition for world market shares $\mathrm{https} / / /$ doi.org/10.1017/CBO9780511549830 
Strange, S. (1996). The retreat of the state: The diffusion of power in the World economy. https://doi.org/10.1017/CBO9780511559143

Sumner, A., \& Tribe, M. A. (2008). International development studies: Theories and methods in research and practice. https://doi.org/10.4135/9781446279397

Torrès-Blay, O. (2000). Economie d'entreprise: Organisation et stratégie à l'aube de la nouvelle économie. Paris: Économica.

Turner, B. S., \& Holton, R. J. (Eds.) (2015). The Routledge international handbook of globalization studies (2nd Revised Edition). Routledge.

Veblen, T. (1899). The theory of the leisure class: An economic study in the evolution of institutions. New York: Macmillan.

Veltz, P. (2000). Le nouveau monde industriel. Paris: Gallimard.

Vernon, R. (1971). Sovereignty at bay: The multinational spread of US enterprises. Thunderbird International Business Review, 13(4), 1-3. https://doi.org/10.1002/tie.5060130401

Vernon, R. (1992). International investment and international trade in the product cycle. International Economic Policies and their Theoretical Foundations (2nd ed.), 415-435. https://doi.org/10.1016/B978-0-12-444281-8.50024-6

Vlados, C. M. (2005). The insertion of greek firms into globalization: The dynamics of the triangle of strategy, technology and management. Tome of Proceedings of International Conference: Managing Global Trends and Challenges in a Turbulent Economy. University of the Aegean: Department of Business Administration.

Vlados, C. M., \& Katimertzopoulos, F. (2017). Local support mechanisms for entrepreneurship: The approach of local development and innovation institutions. International Journal of Business and Economic Sciences Applied Research, 10(1), 30-41. https://doi.org/10.25103/ijbesar.101.04

Vlados, C. M., Deniozos, N., \& Chatzinikolaou, D. (2018a). Towards a new approach of local development under crisis conditions: Empowering the local business ecosystems in greece, by adopting a new local development policy. International Journal of Regional Development, 5(1). https://doi.org/10.5296/ijrd.v5i1.11955

Vlados, C. M., Deniozos, N., Chatzinikolaou, D., \& Demertzis, M. (2018b). Towards an evolutionary understanding of the current global socio-economic crisis and restructuring: From a conjunctural to a structural and evolutionary perspective. Research in World Economy, 9(1). https://doi.org/10.5430/rwe.v9n1p15

von Bertalanffy, L. (1993). Théorie générale des systèmes. Paris: Dunod.

Wallerstein, I. (2012). Robinson's critical appraisal appraised. International Sociology, 27(4), 524-28. https://doi.org/10.1177/0268580912445532

Walras, L. (1874). Éléments d'économie politique pure; ou, Théorie de la richesse sociale, Lausanne: Corbaz.

Warnier, J.-P. (2010). La mondialisation de la culture. Paris: La Découverte.

Weingart, P., \& Padberg, B. (2014). University experiments in interdisciplinarity: Obstacles and opportunities. https://doi.org/10.14361/transcript.9783839426166

Weinstein, O., \& Azoulay, N. (2000). Les compétences de la firme. Revue d'Économie Industrielle, 93(1), 117-154. https://doi.org/10.3406/rei.2000.3007

Wiens, J. J. (2004). What is speciation and how should we study it? The American Naturalist, 163(6), 914-923. https://doi.org/10.1086/386552

Williamson, O. E. (1991). Comparative economic organization: The analysis of discrete structural alternatives. Administrative Science Quarterly, 269-296. https://doi.org/10.2307/2393356

Williamson, O. E. (1999). Strategy research: Governance and competence perspectives. Strategic Management Journal, 20(12) 1087-1108. https://doi.org/10.1002/(SICI)1097-0266(199912)20:12<1087::AID-SMJ71>3.0.CO;2-Z

Williamson, O. E. (2000). The new institutional economics: Taking stock, looking ahead. Journal of Economic Literature, 38(3), 595-613. https://doi.org/10.1257/jel.38.3.595 
Williamson, O. E. (2002). The theory of the firm as governance structure: From choice to contract. Journal of Economic Perspectives, 16(3), 171-195. https://doi.org/10.1257/089533002760278776

\section{Notes}

Note 1. The technostructure according to Galbraith (Galbraith, 1967).

Note 2. The $X$-efficiency according to Liebenstein (Liebenstein, 1987).

\section{Copyrights}

Copyright for this article is retained by the author(s), with first publication rights granted to the journal.

This is an open-access article distributed under the terms and conditions of the Creative Commons Attribution license (http://creativecommons.org/licenses/by/4.0/). 